Original article

\title{
EMILION, a tree functional-structural model: Presentation and first application to the analysis of branch carbon balance
}

\author{
Alexandre Bosc* \\ INRA Pierroton, Station de Recherches Forestières, Laboratoire d'Écophysiologie et Nutrition, BP. 45, 33611 Gazinet Cedex, France
}

(Received 1 February 1999; accepted 30 September 1999)

\begin{abstract}
This paper summarises the main characteristics of a new functional-structural ecophysiological model EMILION elaborated for pine species. It is based on the integration of the functioning of the tree aerial organs, shoots, buds and cones. It is founded on the modelling of carbon- and water- related processes at the organ level, and on the links that exist between the organs. The main processes described by EMILION are light distribution and interception, photosynthesis, respiration, stomatal conductance, transpiration, water transfer, phenology, and intra-annual growth. It uses an object-oriented approach. It has been parameterised and applied to adult Maritime pine (Pinus pinaster Ait.). The model simulates the distribution in the tree of carbon and water fluxes at a short time step. The principal inputs are stand and tree structure, and meteorological data. EMILION allows one to study the interaction of processes at the organ and tree level. An example application is presented, in which EMILION was used to simulate the carbon budget of existing branches, according to their age and location within the crown. This study was used to test one hypothesis of branch death, that death is a consequence of an imbalance between branch assimilate production and use. Our results show that the old branches of Pinus pinaster are autonomous for the carbon, but the ability of these branches to supply assimilates to rest of the tree appears very low. We conclude that this small carbon availability in the oldest branches is a cause of their limited development.
\end{abstract}

Pinus pinaster / functional-structural model / architecture / ecophysiological processes / branch carbon balance

Résumé - Principes du modèle structure-fonction EMILION et application à l'analyse de l'autonomie carbonée des branches dans le houppier. Un nouveau modèle écophysiologique EMILION de type structure-fonction est présenté. Ce modèle élaboré pour les espèces du genre Pinus, est basé sur l'intégration des connaissances relatives au fonctionnement des organes formant l'arbre, il est actuellement adapté au cas du Pin maritime (Pinus pinaster Ait.) adulte. Il s'appuie sur la modélisation des processus carbonés et hydriques à l'échelle de l'organe et sur les relations qu'établissent entre eux les organes qui sont liés. Différents types d'organes aériens sont distingués, les rameaux, les bourgeons et les cônes. Les principaux processus intégrés dans le fonctionnement des organes sont la distribution et l'interception du rayonnement, la photosynthèse, la respiration, la conductance stomatique, la transpiration, les transferts hydriques xylémiens, la phénologie et la croissance intra annuelle. Dans le modèle, chaque organe est représenté par un objet, et un arbre ou une branche par un objet Structure. Le modèle simule les flux de carbone et d'eau au sein de l'arbre à un pas de temps demi-horaire. EMILION permet d'étudier l'interaction des différents processus au sein des organes et au sein de l'arbre. Les entrées du modèle sont la structure du peuplement et de l'arbre modélisé, ainsi que les conditions climatiques. Une utilisation du modèle est présentée. EMILION est utilisé pour simuler, en fonction de leur âge et de leur position dans l'arbre, le bilan de carbone de branches réelles, afin d'analyser les hypothèses expliquant la mort des branches âgées, basées sur un déséquilibre entre production et consommation d'assimilats. Nos résultats montrent que les vieilles branches sont autonomes vis-à-vis du carbone, mais que la quantité d'assimilats quelles sont en mesure de fournir au reste de l'arbre devient relativement faible. Finalement nous supposons que cette faible disponibilité des assimilats, au sein des vieilles branches en peuplement, participe à la limitation de leur développement.

Pinus pinaster / modèle structure-fonction / architecture / processus écophysiologiques / branches / bilan de carbone

* Correspondence and reprints

Tel. 05579790 34; Fax. 05566805 46; e-mail: alexandre.bosc@pierroton.inra.fr 


\section{INTRODUCTION}

Recently more and more models have been developed to describe tree or forest functioning $[3,7,18,21,24$, 28]. A forest manager using production tables to estimate the productivity of his stand is using models without realising it. Such models can take into account several characteristics of the environment (such as site index) through specific parameterisation [19]. However, these models do not deal with the environmental changes that could occur during the stand lifespan, for their only driving force is time. That's why new models of tree functioning emphasise the integration of environmental characteristics. This task is achieved by linking the processes of tree functioning to parameters of the environment [33]. Generally, process-based models describe a tree as a sum of compartments: trunk, branches, foliage, roots, etc. and processes are then evaluated for each compartment.

Mostly, the responses of physiological processes to environmental parameters are non-linear. For example, the response of photosynthesis to light is curvilinear [26], while the dependency of respiration to temperature follows an exponential law [29]. A study of the spatial and temporal variability of these characteristics must be coupled to the analysis of processes studied and parameterised at a level lower than the tree, in order to obtain a reliable model. The first step in integrating the spatial heterogeneity of resource capture is to describe exactly the distribution of the exchange surfaces between the plant and its environment.

Another limitation is occurring with regard to architecture. Here, two main approaches coexist currently. First, the increase of tools to study plant architecture permitted the development of 3D architectural models of several tree species [6]. Although the degree of detail included in these models is high, the motor of growth remains time, and such models remain close to production tables. On the other hand, process-based models are forced to take into account the geometry of trees, that is to say their architecture, in order to be able to estimate more precisely resource capture, especially light interception [33].

A new kind of model, known as functional-structural models [7, 18, 24] were developed more recently in response to the need to considering both the physiological processes and their interactions with the macro and micro environment (outside and inside the tree), with the same accuracy. These models are based on the consideration of the links between the different elements constituting a tree. The model presented in this paper, EMILION (Ecophysiological Modelling Integrating Linked OrgaNs), belongs to this category of models that attempt to represent tree functioning as the integration of the functioning of the tree organs inside a topological structure. The model is specific to pine species and is parameterised for adult maritime pine (Pinus pinaster Ait.). Since total annual growth of the organs is given as an input to the model, EMILION is not a model of growth and development. Instead, it forms an integrative tool of the accumulated knowledge regarding the functioning of plant organs.

The main assumption of EMILION is that plant function can be described in terms of the function of individual organs. In other words, apart from some radiative exchanges (thermal IR, reflected solar radiation), the functioning of a plant is highly bound to the spatial distribution of its tissues, and to their topological organisation.

This paper first presents the principles from which EMILION originates, then gives a brief description of the biological and physical processes introduced in the model. Finally, to illustrate one of the potential uses of the model, we present the study of branch carbon balance, to analyse the links between branch death and branch carbon autonomy. Indeed the realistic modeling of the death of certain organs or whole branches is one of the difficulties raised by the models of the structurefunction type.

\section{MAIN CHARACTERISTICS OF EMILION MODEL}

\subsection{Two levels of organisation}

EMILION is based on two levels of organisation. At the top level, the organisation of trees in the stand, and their main dimensional characteristics, are required. These characteristics, constant during a simulation, define the Scene. The Scene is used to evaluate the radiation conditions in the stand and inside a particular tree.

On the other hand, EMILION splits a tree, or a part of a tree, into discrete units; their size is determined so that their internal functioning can be predicted as well as their behaviour when confronted with other units of the structure. For now, only the aerial part is described, but the same concept could be applied to the whole tree. The entities or organs that are distinguished are buds, shoots and female cones. So far, male flowers have been ignored. In the following, a shoot is defined as the portion of woody axis developed during one growth cycle and the needles borne on this axis. The woody axes of pines - the trunk and the branches - are formed by the succession of shoots. The shoot was chosen as the main 
element of tree structure because it corresponds to a topological unit, it is made up of synchronised and equally functioning internodes, and it bears even-aged needles.

\subsection{Time scale, inputs and outputs of the model}

The maximum duration of a simulation is one year, because EMILION does not model the development of the Scene and the Structure. The model does not include any description of organ emergence. However, if the user is able to indicate the evolutions of the Scene and of the Structure, year after year, the simulations with EMILION permit to obtain results for many years, such as presented in this paper.

The time step is generally fixed to $1 / 50$ day. This relatively short duration is necessary to take into account rapid variations in meteorological conditions, and to correctly model some biological processes, such as stomatal inertia.
The main inputs and outputs of the model are listed in table I. Inputs are: the Scene characteristics, the properties of each organ included in the Structure and the climatic conditions above the stand. The outputs of EMILION are properties evaluated for each organ (geometrical dimensions, biomass, flux,...) and the sum of these variables for a topological group of organs (a branch for example). The meteorological inputs are required at the same frequency as the time step.

\subsection{Program structure of EMILION}

EMILION is coded using an object oriented language because the concepts used in this kind of programming language are quite similar to those defined previously to describe plant functioning. EMILION was implemented in Visual Basic and $\mathrm{C}++$ according to the modules. A functional unit is represented in the computerised model by an object. Objects are classified among object classes, which are defined by their properties and behaviour.

Table I. Main inputs and outputs of the model EMILION.

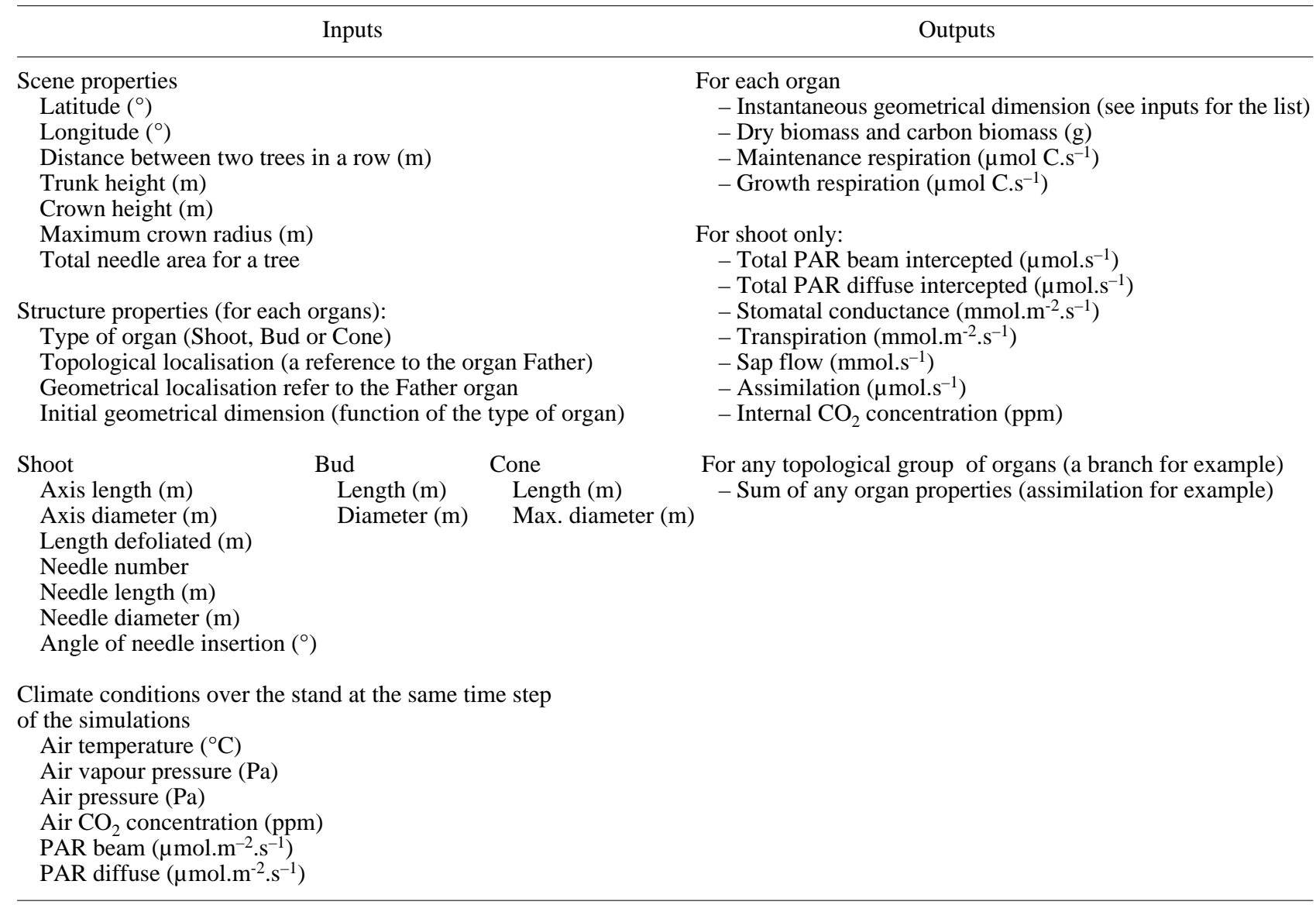


EMILION uses some objects of newly-created classes: for each type of organ that was identified on a plant, an object class was implemented. There are the Shoot class, the Bud class and the Cone class. The code that translates the modelled processes (see below) is included in each class. All three classes share several properties: temporality, geometry and topology. The properties specific to the biological processes are classspecific.

The three classes share the Evaluate method, which is used outside the object to estimate the value of the object properties at each time step. The instances of the Structure class are used to enclose a set of organs interconnected by topological links. For example, a branch or a tree is represented by an object from the Structure class.

The MicroClimate class is used to create objects describing the microclimate around each organ. The code used to evaluate the microclimate at a particular location inside a tree, using climate and tree structure data, is included in this class.

The running procedure of the model is basic and managed through a Simulator. At first, the model is initialised with a tree or branch structure, and some dimensions that are not provided with this structure. Then, using the time variable as an argument, the Simulator runs iteratively the method Evaluate to update the object properties. It also extracts information from the structure, synthesises the data and saves them. For each time step, the model evaluates the MicroClimate and the oldest Organ of the structure. This Organ transmits the Evaluate method to the organs that it is bearing, and this procedure is repeated iteratively over the whole structure.

The characteristics of the stand climate are input data provided by an external module. Before each simulation, the user can specify the time period for the simulation, the time step, and the properties, which are to be saved. The Simulator code can be adapted to any particular need of the user.

\section{THE MAIN PROCESSES CONSIDERED IN EMILION}

In the present version of EMILION, carbon assimilation, circulation and consumption, water circulation and water loss (transpiration) are the main processes considered to describe the functioning of the organ classes presented previously. We will briefly present here the major processes implemented for each organ class.

EMILION was parameterised mainly with the characteristics measured on a 27 year-old Pinus pinaster stand, called the Bray site (EUROFLUX Site FR1) [1, 9, 13, $20,26]$.

\subsection{Climatic processes}

\section{Micro climatic conditions}

Each organ is associated with a MicroClimate object, which contains the microclimate characteristics at the organ location. The variables provided by the MicroClimate object are the following: air temperature $\mathrm{Ta}\left({ }^{\circ} \mathrm{C}\right)$, water vapour pressure $e(\mathrm{~Pa})$, vapour pressure deficit VPD $(\mathrm{Pa})$, air $\mathrm{CO}_{2}$ concentration $\mathrm{Ca}(\mathrm{ppm})$, atmospheric pressure $P(\mathrm{~Pa})$, direct PAR (photosynthetically active radiation) $I_{\text {dir }}$, downward diffuse PAR $I_{\text {diff }}^{+}$ and upward diffuse PAR $I_{\text {diff }}^{-}$. Except for $I_{\text {dir }}, I_{\text {diff }}^{+}$and $I_{\text {diff }}^{-}$, these properties are set equal to the parameter values at the stand level.

\section{Light distribution in the stand}

The PAR intensities at a particular location $\left(I_{\mathrm{dir}}, I_{\mathrm{diff}}^{+}\right.$ and $\left.I_{\text {diff }}^{-}\right)$were calculated using a hybrid model combining the geometrical shape of the tree with the approach of radiation attenuation in a turbid medium. For all Scene's trees, the crown shape is modelled by a volume with a trunk as a symmetry axis; it was established on adult Maritime pine by Porté et al. [26]. Only two parameters are needed to define this volume: crown height and maximal radius. The attenuation of radiation within the stand, evaluated using Beer's law [1], is function of the leaf area density cumulated along the path of the radiation. Two beta functions define the vertical and radial distribution of leaf area density within the crown $[2,26]$. The cumulated area density is numerically evaluated each ten centimetres along the radiation path.

Diffuse incident radiation is treated as a set of directional sources, i.e. integrating directional interception contributions over the whole sky. For this the sky is divided into solid angle sectors. The contribution of each solid angle to the fractional diffuse radiation at a particular location, is evaluated from radiation attenuation along a path centred on that solid angle. The PAR redifusion is not taken into account.

\section{Shoot light interception}

The modeling of shoot light interception is an important part of EMILION. The incident radiation of each organ is provided by the MicroClimate object, associated with the Shoot object. Radiation interception by a shoot depends upon (1) its geometry [2, 23, 34] and (2) its orientation towards the light source [22].

Shoot geometry changes significantly once foliated ( 3 or 4 year-old period for Maritime pine) (figure 1). During the first year, needles elongate slowly to reach 


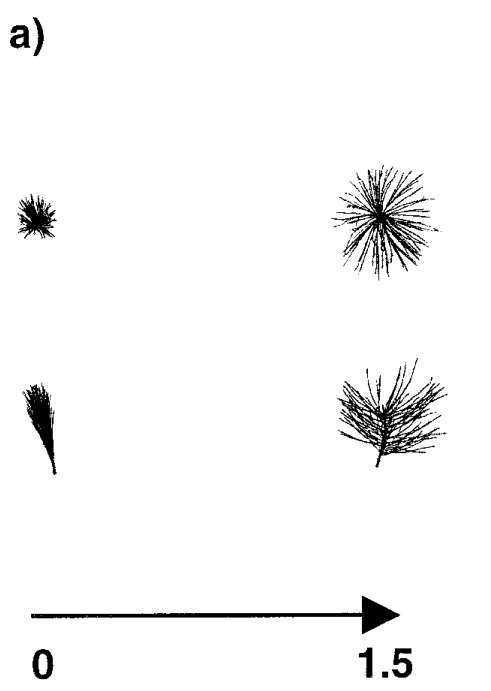

b)
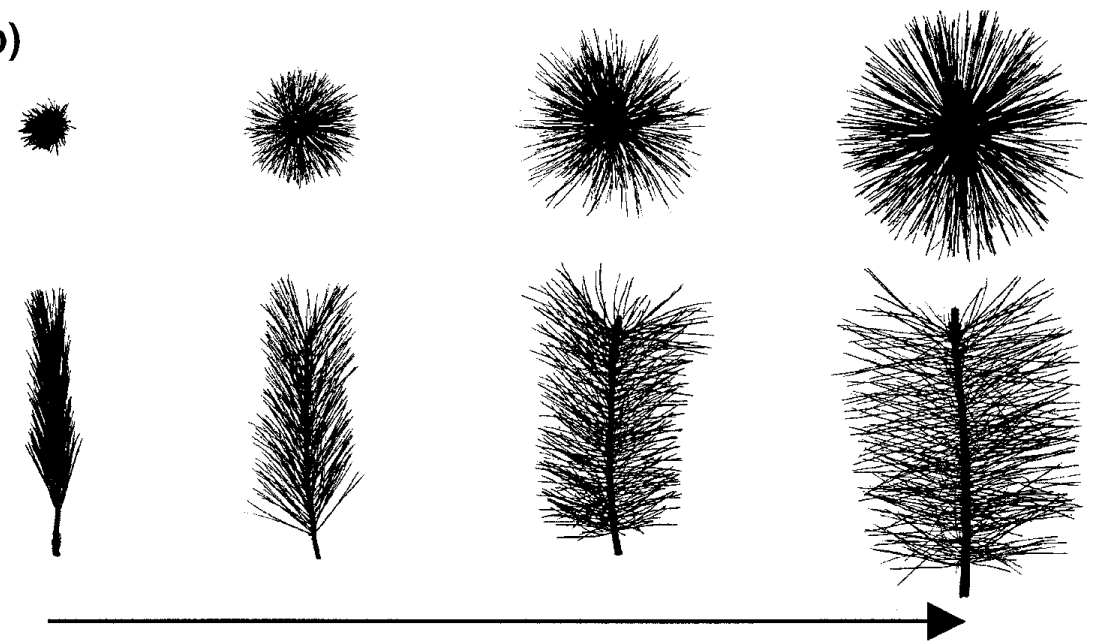

0

\section{Shoot age (year)}

Figure 1. Examples of Pinus pinaster shoot projections, illustrating the importance of shoot geometric evolution with time. Projections perpendicular to and in the direction of their woody axes are presented for two different shoots: (a) at the bottom of the crown and (b) at the top of the crown.

their maximal length: the assimilating area increases but needles are very close to the shoot axis, which results in considerable self-shading. From the first winter to the end of the second growing season, needles open up to become almost perpendicular to the woody axis. The foliage area of the shoot then begins to reduce as a consequence of needle fall. The evolution of the internal geometry of the shoot coincides with a modification of the general orientation of the shoot. It starts with an erect position and bends progressively while ageing.

The radiation, $E(\Omega)$ (mol photon. $\mathrm{s}^{-1}$ ), parallel to the direction of space $\Omega(\theta, \phi)$ ( $\theta$ angle of incidence, $\phi$ azimuth) intercepted by a shoot, is given by the following equation:

$$
E(\Omega)=I(\Omega) \cdot S S A(\Omega) .
$$

With $I(\Omega)$ (mol photon. $\mathrm{m}^{-2} \cdot \mathrm{s}^{-1}$ ) is the intensity of the radiation parallel to the $\Omega$ direction and $\operatorname{SSA}(\Omega)$ is the projected area of the shoot on a plane perpendicular to $\Omega$ ( $S S A$ : Shoot Silhouette Area $-\mathrm{m}^{2}$ ). The intercepted direct PAR $E_{\text {dir }}$ (mol photon. $\mathrm{s}^{-1}$ ) is calculated using equation (1), with $I=I_{\text {dir }}$ (the intensity of the incident direct PAR) and $\Omega=\Omega_{\text {sun }}$ (the sun beam direction). To calculate the total diffuse intercepted radiation, we integrated equation (1) over the two upper and lower halves of the sky vault. Under the hypothesis of isotropic lumi- nance, the diffuse intercepted radiation; $E_{\text {diff }}$ (mol photon. $\mathrm{s}^{-1}$ ) is simply expressed by the equation:

$$
E_{\mathrm{diff}}=2\left(I_{\mathrm{diff}}^{+}+I_{\mathrm{diff}}^{-}\right) \cdot \overline{S S A} .
$$

$\overline{S S A}\left(\mathrm{~m}^{2}\right)$ is the mean of the shoot silhouette area projected according to all directions in space [22]. The mean intensity of diffuse intercepted PAR per surface unit, $\overline{I_{\text {dif }}}$ (mol photon. $\mathrm{m}^{-2} \cdot \mathrm{s}^{-1}$ ) is the ratio of the diffuse PAR intercepted by the shoot to its total leaf area, $S A$ $\left(\mathrm{m}^{2}\right)$ :

$$
\overline{I_{\mathrm{dif}}}=\frac{E_{\mathrm{dif}}}{S A} .
$$

$\overline{I_{\text {dif }}}$ is used to evaluate the photosynthesis of shaded needles.

It is difficult to evaluate analytically the value of the SSA of a shoot [34] and it requires some geometrical simplification. Using images of projected shoot 3D models, we obtained highly accurate estimate of the $S S A$ value. In addition, these images can be used to estimate the developed needle area $S A_{\mathrm{I}}(\Omega)$ that intercepts radiation coming from a particular direction [2], which is required in the photosynthesis module. However, it is a time consuming procedure that would handicap the 
model too much. Therefore, in EMILION, SSA, $\overline{S S A}$ and $S A_{\text {sun }}$ (see below) were calculated with multivariable regressions parameterised on a large set of measurements (projected 3D models covering the range of the shoot silhouettes encountered in the field) [2].

\subsection{Biological processes at the organ level}

\section{Shoot photosynthesis}

Photosynthetic gas exchange is calculated according to the biochemical model of Farquhar [11], which was parameterised for adult Maritime pine by Porté and Loustau [27]. It is coupled to the modelling of PAR interception described previously.

Uniform values of the Farquhar model parameters [11], $V_{\text {cmax }}, J_{\max }, \alpha$ and $R_{\mathrm{d}}$, are used for the whole shoot. The effects of needle age and needle temperature are included in the model using the following equation:

$$
i(\text { Age, } T)=p(0,25) * f_{\text {age }}(\text { Age }) * f_{\mathrm{T}}(T)
$$

Where Age is the needle age (year), $T$ the needle temperature $\left({ }^{\circ} \mathrm{C}\right)$, and $p$ one of the photosynthetic parameters. Values of $p(0,25), f_{\text {age }}$ and $f_{\mathrm{T}}$ for each photosynthetic parameter are presented in table II.

Shoot assimilation is calculated as the sum of the assimilation of two needle areas, $S A_{\text {sun }}$ and $S A_{\text {shade, }}$ according to the results of Bosc [2]. $S A_{\text {sun }}\left(\mathrm{m}^{2}\right)$ is equal to the total surface of the needle segments that have a face illuminated directly by the sun. $S A_{\text {shade }}$ is equal to the difference between total shoot area $(S A)$ and $S A_{\text {sun }}$. We assumed that $S A_{\text {sun }}$ has the same photosynthetic rate as a needle area illuminated by a radiation intensity of $E_{\text {dir }} / S A_{\text {sun }}+\overline{I_{\text {dif }}}$, and that $S A_{\text {shade }}$ has a photosynthetic rate equal to that of a surface receiving $\overline{I_{\text {dif }}}$.

\section{Stomatal conductance}

The whole needle area of a shoot has a unique stomatal conductance to water vapour, $g_{\mathrm{w}}\left(\mathrm{mmol} \cdot \mathrm{m}^{-2} \cdot \mathrm{s}^{-1}\right)$. The sub module that calculates $g_{\mathrm{w}}$ adds the consideration of stomatal inertia to a multiplicative Jarvis-type approach [15]. Steady-state stomatal conductance $g_{\mathrm{w}_{\text {equi }}}$ is expressed by:

$$
g_{\mathrm{w}_{\text {equi }}}=g_{\mathrm{w}_{\text {max }}} \cdot f_{1}(\mathrm{D}) \cdot f_{2}(\mathrm{PAR}) \cdot f_{3}(\Psi)
$$

with $g_{\mathrm{w}_{\max }}$ the maximum value of $g_{\mathrm{w}}, f_{1}, f_{2}$ and $f_{3}$ describing the stomatal response to air vapour pressure deficit (D), total intercepted PAR per leaf area unit and predawn water potential respectively.

The inertia of stomatal reaction to environmental changes is introduced in the model by considering that an instantaneous variation of stomatal conductance $g_{\mathrm{w}}$ is proportional to the difference between $g_{\mathrm{w}_{\text {equi }}}$ and $g_{\mathrm{w}}$ :

$$
\frac{\mathrm{d} g_{w}}{\mathrm{~d} t}=\frac{\ln (2)}{\tau} \cdot\left(g_{\mathrm{w}_{\text {equi }}}-g_{\mathrm{w}}\right) .
$$

where $\tau$ is the time of half-reaction. Between two time steps of the model, we considered that $g_{\mathrm{w}_{\text {equi }}}$ follows a linear evolution, in order to be able to solve the differential equation (6).

The parameters $g_{\mathrm{w}_{\max }}, f_{1}(\mathrm{D}), f_{2}(\mathrm{PAR}), f_{3}(\Psi)$ and $\tau$ were derived from continuous gas exchange measurements done on Pinus pinaster shoots [2].

\section{Transpiration and sap flow}

Only the shoots are transpiring organs and sap flow conductors. Shoot transpiration is simply represented as the product of the shoot stomatal conductance with its leaf area and the water vapour pressure gradient between the sub-stomatal chamber and the ambient air [12]. We consider that leaf temperature is equal to that of air.

The sap flow $F\left(\mathrm{~mol} \mathrm{H}_{2} \mathrm{O} . \mathrm{s}^{-1}\right)$ that enters a shoot is assumed equal to the sum of the shoot's transpiration, plus the sap flows entering the shoots that are supported by it.

\section{Phenology and growth}

In the present version of EMILION, neither growth nor new organ initiation were modelled by a "biological"

Table II. Parameters values used to evaluate the photosynthetic parameters $V_{\text {cmax }}, J_{\max }, \alpha$, and $R_{\mathrm{d}}$ as a function of needle age Age (year) and needle temperature $T\left({ }^{\circ} \mathrm{C}\right)$. Adapted from Porté and Loustau [18].

\begin{tabular}{lccc}
\hline $\begin{array}{c}\text { Photosynthetic parameters } \\
\text { and units }\end{array}$ & $\begin{array}{c}\text { Reference value } \\
\left.\text { Age }=0, T=25^{\circ} \mathrm{C}\right)\end{array}$ & $f_{\text {age }}$ & $f_{\mathrm{T}}$ \\
\hline$V_{\mathrm{cmax}}\left(\mu \mathrm{mol} . \mathrm{m}^{-2} \cdot \mathrm{s}^{-1}\right)$ & 69.1 & $1-0.232$ Age & $1-0.0025(T-25)^{2}$ \\
$J_{\max }\left(\mu \mathrm{mol} \cdot \mathrm{m}^{-2} \cdot \mathrm{s}^{-1}\right)$ & 137.4 & $1-0.202$ Age & $1-0.0025(T-25)^{2}$ \\
$\alpha$ & 0.178 & $1-0.172$ Age & 1 \\
$R_{\mathrm{d}} \quad\left(\mu \mathrm{mol} \mathrm{e} \cdot \mathrm{mol}^{-2} \cdot \mathrm{s}^{-1}\right)$ & 0.37 & 1 & $2^{(T-25) / 10}$ \\
\hline
\end{tabular}


process. In the case of Maritime pine, these processes are still very poorly understood. Nowadays, models that deal with carbon allocation or growth limitation in response to the availability of resources are only theoretical [4, $18]$. We choose not to force the model by electing one of
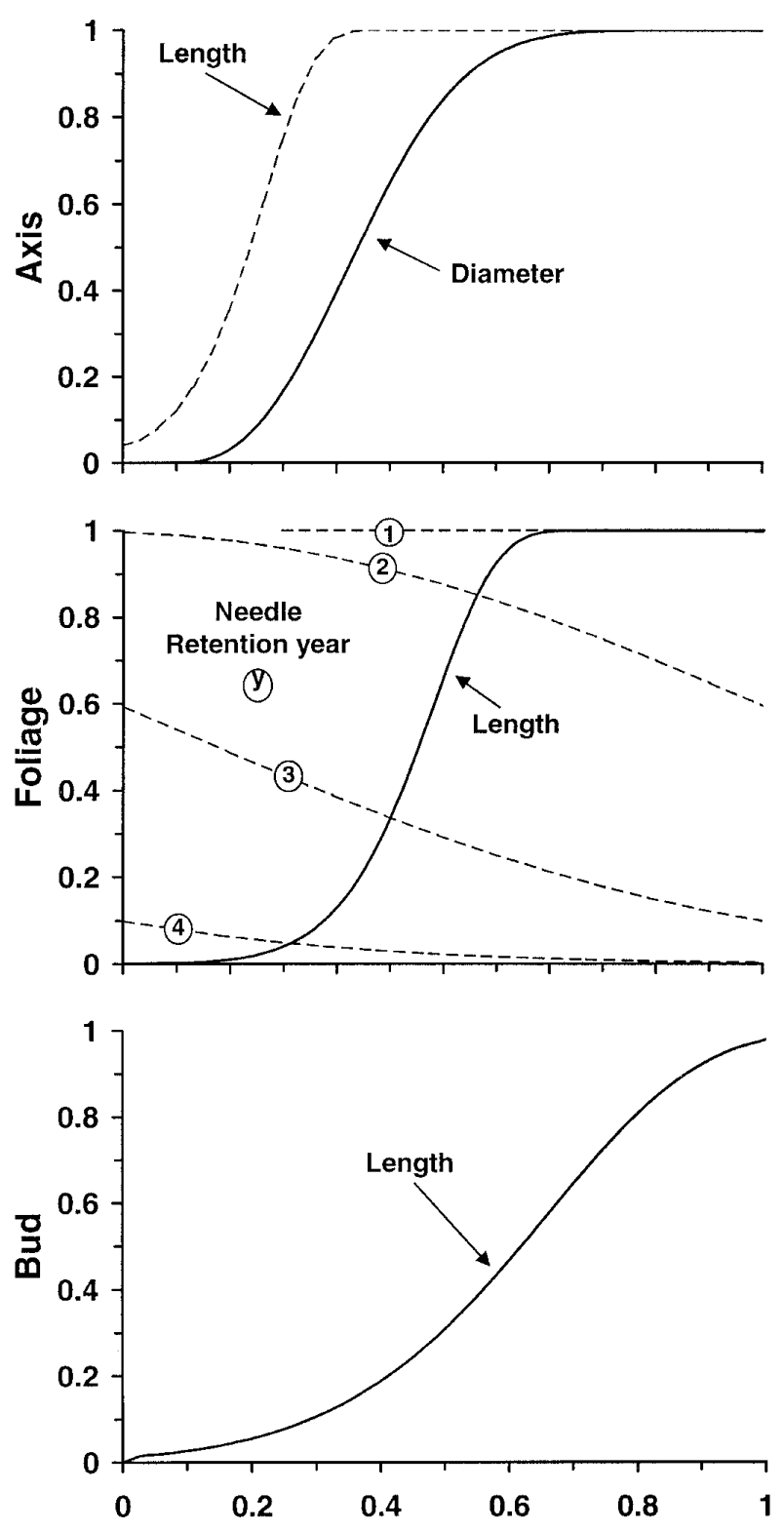

Normalised phenological year

Figure 2. Phenograms for Pinus pinaster, with the $y$-axis representing the cumulative development of each variable on a 0 to 1 scale and the $x$-axis representing a normalised phenological year where 0 is date of bud burst [2]. these theoretical concepts. Consequently, to simulate the dimension increments of any organ, EMILION requires the knowledge of its initial and final dimensions. The evolution with time between these two states of development follows the mean phenology of each organ type (figure 2) which are known for Maritime pine [2]. Each year the day of bud burst is calculated using degree-day sum [8]. This date is then used as a reference for all phenological processes.

\section{Assimilate use}

Figure 3 schematically represents the carbon fluxes and pools of a shoot. The photosynthetic flux has been described previously. Carbon is incorporated in to the organ structure during growth. We assume that dry matter by unit volume and carbon concentration are constant for each tissue type (table III). Respiration is calculated by separating growth respiration $R_{\mathrm{g}}\left(\mathrm{mol} \mathrm{C} . \mathrm{s}^{-1}\right)$ from maintenance respiration $R_{\mathrm{m}}\left(\mathrm{mol} \mathrm{C} . \mathrm{s}^{-1}\right)$. The energetic construction costs applied to calculate growth

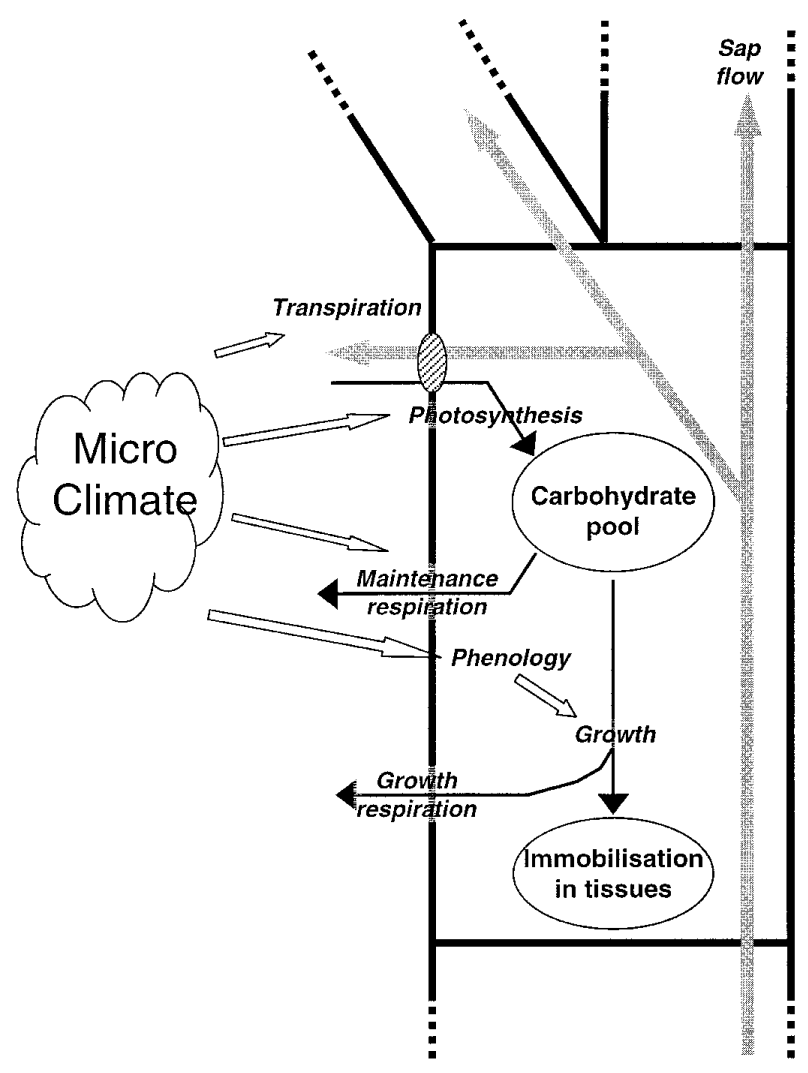

Figure 3. Processes integrated in each object Shoot. They are the main processes related to the carbon and water cycles. 
Table III. Dry density and C concentration used to evaluated the carbon fixed in the tissues. Energetic construction cost, applied to calculate growth respiration. * Jactel personal communication, ${ }^{* *}$ Porté [26], ${ }^{* * *}$ based on the synthesis of Pooter and Villar [25], default values.

\begin{tabular}{lccc}
\hline Tissue & $\begin{array}{c}\text { Dry density } \\
\text { g.cm }\end{array}$ & $\begin{array}{c}\text { C concentration } \\
\text { g.g }{ }^{-1}\end{array}$ & $\begin{array}{c}\text { Construction cost } \\
\text { mol C.mol C }\end{array}$ \\
\hline Axis & $0.40^{* *}$ & $0.444^{*}$ & $0.351^{* * * *}$ \\
Needles & $0.43^{* *}$ & $0.500^{*}$ & $0.232^{* * * *}$ \\
Buds & $0.40 "$ & $0.444^{*}$ & $0.351^{* * * *}$ \\
Cones & $0.40^{*}$ & $0.444^{* *}$ & $0.351^{* * *}$ \\
\hline
\end{tabular}

respiration, are specific to the tissues (table III). Maintenance respiration follows the classical formula [29]:

$$
R_{\mathrm{m}}=R_{\mathrm{m}_{15}} \cdot Q_{10} \frac{(T-15)}{10}
$$

Where $R_{\mathrm{m}_{15}}$ is the maintenance respiration of the organ at the reference temperature $\left(15^{\circ} \mathrm{C}\right)$, and $Q_{10}$ the increase factor of $R_{\mathrm{m}}$ for a $10{ }^{\circ} \mathrm{C}$ increment in the organ temperature $T$. Relationships between $R_{\mathrm{m}_{15}}$ and the properties of the three organ types are different and were derived from experiments done in our laboratory [2]. For buds and cones, $R_{\mathrm{m}_{15}}$ is proportional to the organ volume. For shoots, $R_{\mathrm{m}_{15}}$ is the sum of the needles maintenance respiration (proportional to needle area) with the woody axis maintenance respiration, calculated as follows:

$$
R_{\mathrm{m}_{15}}=a \cdot \frac{\operatorname{Dia}^{b}}{\operatorname{Age}^{c}} \cdot L g .
$$

Parameters $a, b$ and $c$ are positive and common to all the axes of a tree [2]. Consequently, for a same diameter and per unit length, respiration decreases with age, reflecting differences in axis vitality.

\section{APPLICATION OF EMILION TO THE ANALYSIS OF BRANCH CARBON BALANCE}

Pruning of the oldest branches is a natural process in stands and it plays an important role in the tree development. We don't know exactly what are the phenomena that lead to branch death, but several hypotheses have been proposed. (1) Death could be the result of a total embolism of the branch: an ageing branch shows a more and more complex structure, which results in a decrease of the hydraulic conductance between the trunk and the transpiring area of the branch. Other hypotheses are based on the branch carbon budget. (2) Death occurs when a branch no larger produces enough carbohydrate to maintain and develop its structure [29]. (3) Branch death occurs even before any carbon deficit, as soon as the water and mineral use efficiencies (the carbon production compared to the required water or mineral use) become too low [35].

Experimental or theoretical studies concerning links between branch death and carbon budget are rare [5, 35]. EMILION was used to explore the hypothesis of branch death linked to the carbon balance. Branch carbon balance $(C B)$ corresponds here to the difference between its assimilation $(A)$ and the carbon used for growth $(G)$ and respiration $(R)$ processes:

$$
C B=A-G-R .
$$

Equation (10) expresses the organ carbon conservation. $\Delta C$ corresponds to the variation in the non-structural carbon pool and $E$ to carbon exportation.

$$
\Delta C=A-G-R-E \rightarrow C B=E-\Delta C .
$$

We assume that over a one year period, $\Delta C$ can be ignored when compared to $E$, and the annual branch carbon balance $\left(C B_{\mathrm{Y}}\right)$ can be considered equivalent to the export to the tree.

\subsection{Material and methods}

The study was done on three 28 year-old Maritime pines from the Bray site, which is located $20 \mathrm{~km}$ southwest of Bordeaux, France $\left(44^{\circ} 42 \mathrm{~N}, 0^{\circ} 46 \mathrm{~W}\right)$. The mean annual temperature is $12.5^{\circ} \mathrm{C}$ and annual rainfall averages $930 \mathrm{~mm}$ (1951-1990). Other site characteristics can be found in Granier and Loustau [35]. In 1997, mean tree height was $18.3 \mathrm{~m}$ and mean tree DBH $28.1 \mathrm{~cm}$. Tree crowns were made accessible with several scaffoldings. Fifteen branches were selected early in the season: on each tree, if possible one pair of branches was selected in the top, middle and bottom thirds of the crown. We followed the growth of these branches during the season and pruned at the end of the growing season for intensive architecture measurements. For each growth unit, the length, median diameter, and number of needles were measured, and measurements made on five pairs of needles were used to estimate the average needle length, diameter, and insertion angle. We also measured the length and diameter of the buds and female cones. The location in space of each organ was estimated using the growth unit lengths and 3D measurements of the branch insertion point and of the tips of each ramification: the shoot of the main branch axis was assumed to be situated on a arc of circle, and other ramified shoots on straight 
Table IV. 1998 structural characteristics of the branches used in the simulations.

\begin{tabular}{|c|c|c|c|c|c|c|c|c|c|}
\hline \multirow[t]{2}{*}{ Branch } & \multirow{2}{*}{$\begin{array}{l}\text { Year of } \\
\text { emergence }\end{array}$} & \multirow{2}{*}{$\begin{array}{l}\text { Age } \\
\text { (year) }\end{array}$} & \multirow{2}{*}{$\begin{array}{l}\text { Orientation } \\
\left(^{\circ}\right)\end{array}$} & \multicolumn{3}{|c|}{ Number of living organs } & \multirow{2}{*}{$\begin{array}{l}\text { Length of } \\
\text { main axis } \\
(\mathrm{m})\end{array}$} & \multirow{2}{*}{$\begin{array}{l}\text { Total leaf } \\
\text { area }\left(\mathrm{m}^{2}\right)\end{array}$} & \multirow{2}{*}{$\begin{array}{c}\text { Total axis } \\
\text { biomass } \\
\text { (g) }\end{array}$} \\
\hline & & & & Shoot & Cone & Bud & & & \\
\hline b1 & 1991 & 8 & 270 & 62 & & 13 & 2.35 & 0.59 & 554 \\
\hline b2 & 1991 & 8 & 225 & 77 & & 16 & 2.51 & 0.96 & 674 \\
\hline b3 & 1996 & 3 & 338 & 10 & 2 & 5 & 1.20 & 1.19 & 319 \\
\hline b4 & 1996 & 3 & 22 & 15 & 1 & 7 & 1.32 & 1.73 & 443 \\
\hline b5 & 1994 & 5 & 180 & 37 & & 13 & 2.17 & 2.39 & 743 \\
\hline b6 & 1994 & 5 & 225 & 37 & & 13 & 1.99 & 1.25 & 501 \\
\hline b8 & 1997 & 2 & 22 & 6 & & 5 & 0.99 & 1.21 & 205 \\
\hline b9 & 1991 & 8 & 22 & 63 & & 12 & 2.50 & 0.83 & 663 \\
\hline b10 & 1990 & 9 & 135 & 109 & & 24 & 3.01 & 1.51 & 1120 \\
\hline b11 & 1992 & 7 & 248 & 112 & & 34 & 3.05 & 2.53 & 1615 \\
\hline b12 & 1991 & 8 & 90 & 129 & & 39 & 3.08 & 1.37 & 1307 \\
\hline b13 & 1989 & 10 & 112 & 159 & & 35 & 2.92 & 1.35 & 1164 \\
\hline b14 & 1992 & 7 & 68 & 112 & 1 & 34 & 3.05 & 2.57 & 1608 \\
\hline b16 & 1996 & 3 & 45 & 10 & & 6 & 1.18 & 1.28 & 269 \\
\hline b18 & 1993 & 6 & 225 & 62 & & 24 & 2.29 & 1.58 & 865 \\
\hline
\end{tabular}

line [2]. The characteristics of the branches are listed in table $I V$. By the end of the year 1998, none of the studied branches had died.

In EMILION model, Structure objects were created to represent the measured branches. Based on the architectural analysis, Structure objects were also created to obtain retrospective representations of the branches, from their birth to their present age. The axis diameter at age $n$, at the beginning of the growing season $\left(D i a_{\text {ini }}\right)$, was estimated using the following equation:

$$
D i a_{\text {ini }}(n-1)=D i a_{\text {ini }}(n) \cdot\left(\frac{n-1}{n}\right)^{0.385}
$$

The characteristics (length, diameter, initial number) of the needles borne by the shoots, were set proportional to the shoot length during the early ages of the branch. These relationships and equation (11) were parameterised using analysis of rings from several growth units from branches collected on the same stand.

Three sets of simulations were executed with EMILION: First, using the real climate, we simulated branch functioning throughout their life, for 3 to 9 years, according to branch age. Secondly, to evaluate the limitations of carbon balance due to environmental factors for the oldest branches, we simulated the functioning of one particular branch (b10) of age 9, in the absence of one of the following limitations: reduction of radiation due to (1) other trees, (2) or all needle area, limitation of stomatal conductance due to (3) radiation, (4) air vapour pressure deficit or (5) soil water potential. Finally, to test the effects of annual climatic conditions, we simulated one year of the functioning of actual branch structure with annual climatic conditions of the period 1980-1998.

The climatic data used were those of the meteorological station of Merignac, situated $20 \mathrm{~km}$ from the Bray site. The time step was 0.02 day. After each time step, the set of variables required to calculate the branch carbon balance was retained: assimilation cumulated over all the shoots of the branch, as well as the cumulated components of respiration and the cumulated components of growth. Moreover, for each branch, and at each time step $(t)$, we calculated the carbon balance of the branch from the beginning of the year to time $t(C B(t))$. On the 1 st of January, $C B(t)=0$, and on the 31 st of December, $C B(t)=C B_{\mathrm{Y}}$ the annual branch carbon balance.

\subsection{Results and discussion}

The instantaneous carbon balance of branches is the result of their activities: photosynthesis, respiration and growth. This is negative during the night, generally positive the day, and variable according to the season and the climatic conditions. CB cumulated over a large period indicates the ability of a branch to export carbon.

Figure 4 presents the changes with age in the annual carbon balance $C B_{\mathrm{Y}}$ of each branch, and the average for all branches. The average behaviour of branches was characterised by (1) a small deficit in carbon fixation

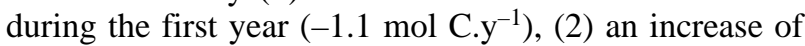
$C B_{\mathrm{Y}}$ up to the age of 4, (3) its stabilisation at $30 \mathrm{~mol}$ C. $\mathrm{y}^{-1}$ during three years (4-6) and (4) afterwards a 


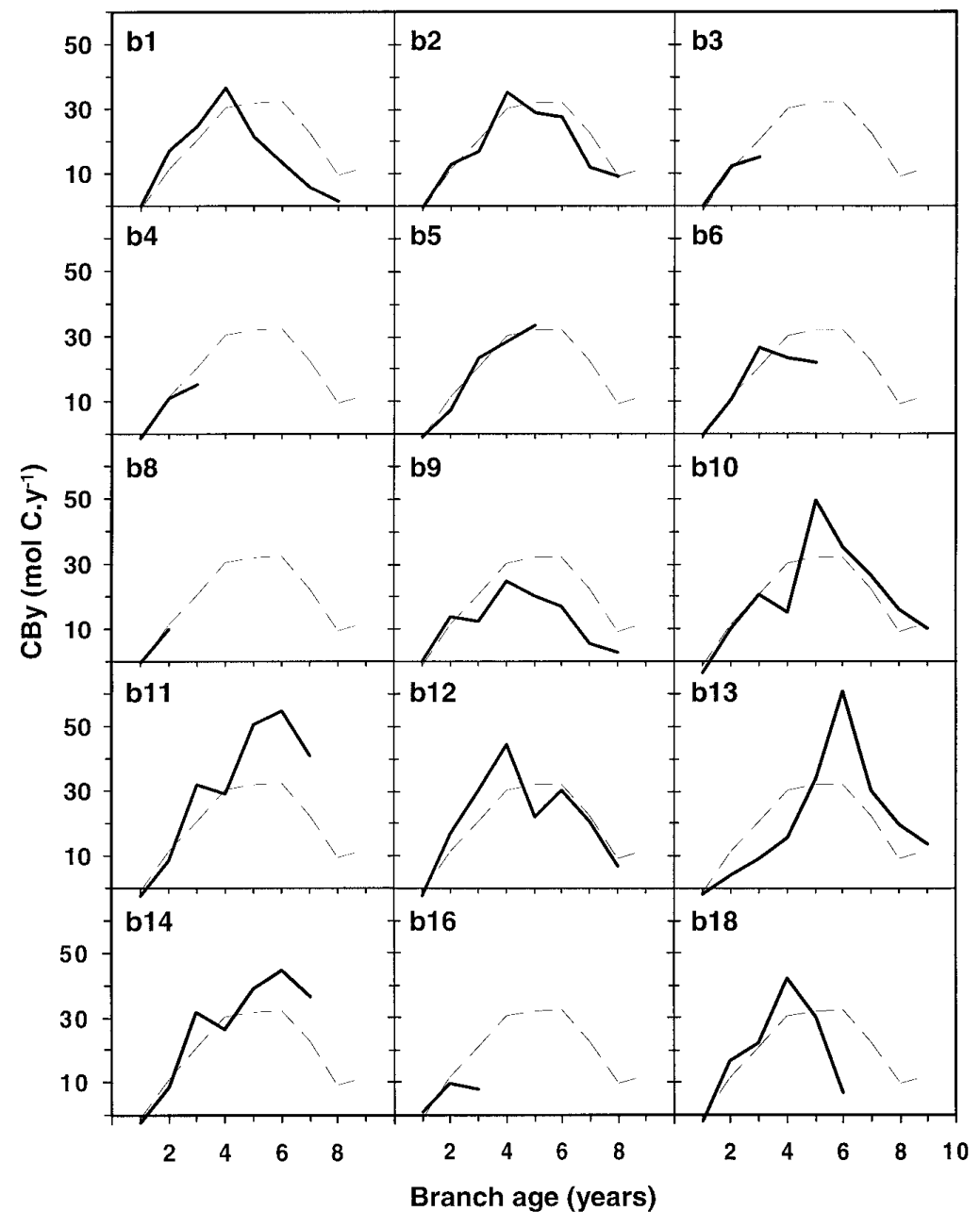

Figure 4. Evolution of annual carbon balance $\left(C B_{\mathrm{Y}}\right)$ of Pinus pinaster branches during their life time. On each graph, the solid line represents the target branch, and the dotted line the average of all studied branches. continuous decrease of $C B_{\mathrm{Y}}$. Except for the first year, $C B_{\mathrm{Y}}$ was always positive.

The evolution of $C B_{\mathrm{Y}}$ with age looked the same from one branch to another, although there could be some important differences. Maximal value of $C B_{\mathrm{Y}}$ was not reached at the same age for all the branches (4-6). For the same age, the ability of some branches to export carbon was two or three times larger than for some others. For many branches (b9, b10, b11, 12, b14), the evolution of $C B_{\mathrm{Y}}$ was characterised by an inflexion point at the age of 3 or 4 . It is noteworthy that there was no clear relationship between the initial $C B_{\mathrm{Y}}$ and the final $C B_{\mathrm{Y}}$ of a branch. For instance, branch b13 presented the worst carbon balance at the age of 3 , whereas it reached one of the highest values at the age of 5 .

The variation in $C B_{\mathrm{Y}}$ during branch life time resulted from variations in its components. Figure 5 illustrates these evolutions for branch b10. For this branch, net assimilation reached its maximum (88.4 mol C. $\left.\mathrm{y}^{-1}\right)$ at 5 years of age (figure $5 a$ ), when the branch reached its maximal needle mass, and then decreased because of needle shedding and light attenuation inside the canopy. Similarly the carbon used by this branch increased up to 4 year-old and decreased later. However this decrease was less important than that of the assimilation, which resulted in an increase of the self-consumption of carbohydrates from the age of 5 . Until 4 years of age, the increase in carbon used by branch b10 is a consequence of increases in all sinks for carbon (figure $5 b$ ). Later there was a reduction of the annual needle biomass production and a stabilisation in the annual production of axis and bud biomass. In spite of this stabilisation, the respiratory cost of these tissues continued to rise.

The characteristics of the carbon components of all other studied branches (data not shown) were similar to those of branch b10. It appeared that the inflexions 
Figure 5. Evolution of the $C B_{Y}$ components during the life of a 9 year-old Pinus pinaster branch (b10). a) Crosses represent assimilation and open symbols the total carbon use. b) The latter is separated between costs of maintenance and growth for all organ types (axis and bud are group together).

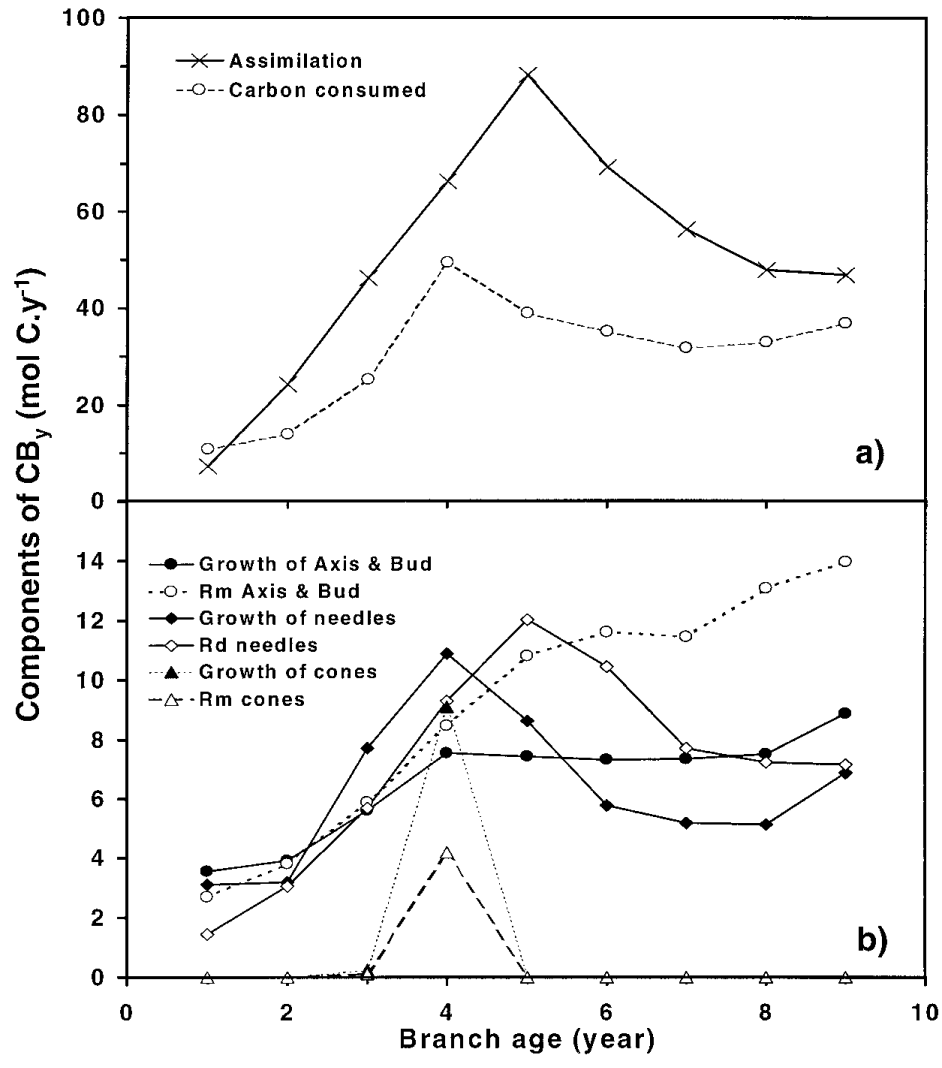

reduced, it reflects that at that time, the carbon used in growth and respiration processes overcome the carbon gain resulting from assimilation. This implies that either the branch has to draw from the non-structural carbon storage, or that carbon has to be imported from somewhere else in the tree. As for the youngest branch at the beginning of its life, it is likely a carbon sink for the tree.

Branch death, as observed in the field, occurs during a relatively short period. It takes place between the end of July and mid-September, which coincides with the time when branches demonstrate a reduction in cumulated carbon balance (figure 6). Witowski [35] made a similar observation for Pinus sylvestris. Although $C B(t)$ remained positive for old branches, there are two further hypothese related to carbon balance that could explain the fact that Pinus pinaster branch death occurres during the end of summer. First, it is possible that carbohydrate pools are very low in this season, more so than the $C B(t)$ value, as a result of important export during the beginning of the year to supply the assimilates needed for trunk and root tissue growth. This phenomenon could be more pronounced for the old branches that situated at the bottom of crown, near the trunk and roots. On the other hand, it is also possible that death is the result of immobilisation in structural growth (figure 2) and to water stress, respectively. When the $C B(t)$ of a branch is 


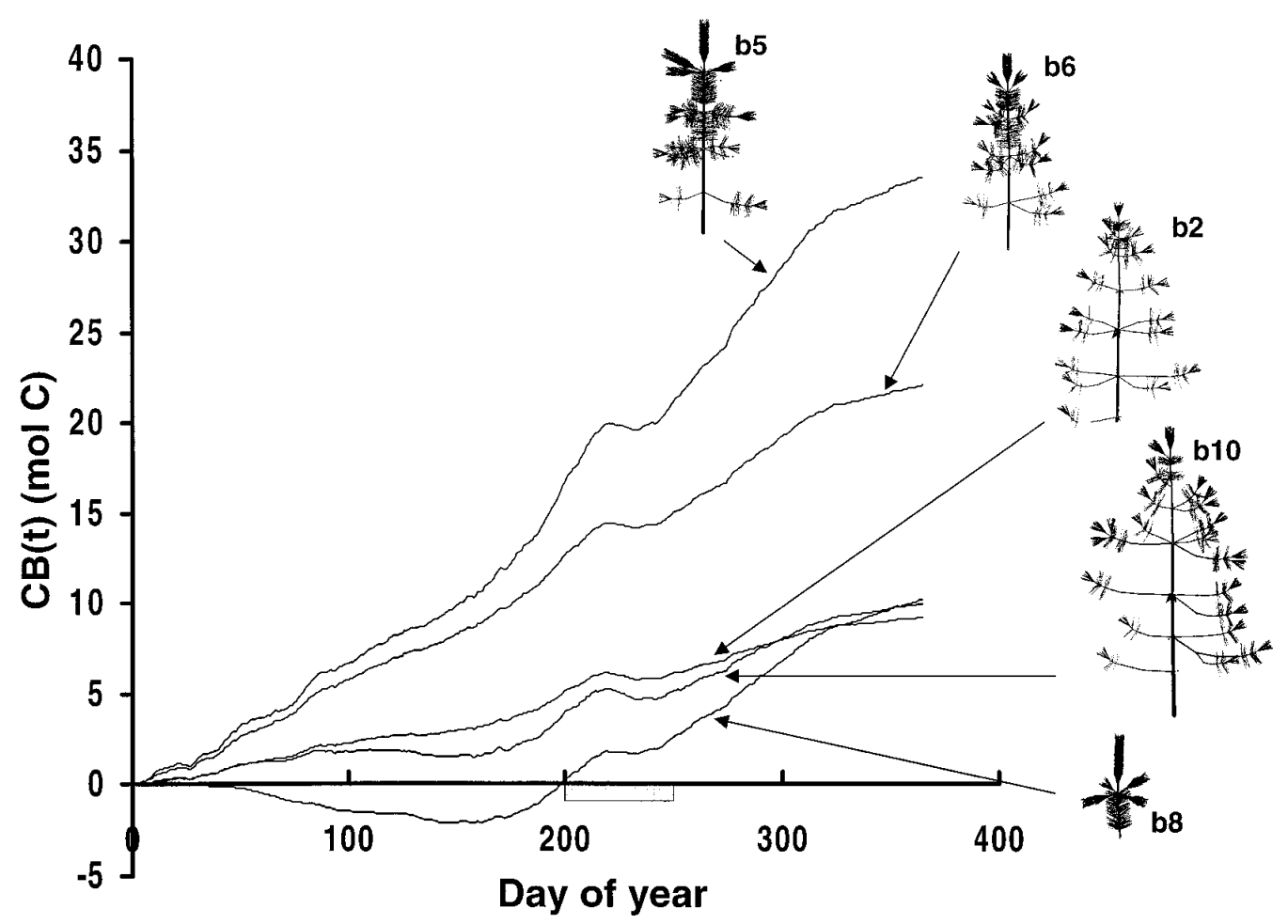

Figure 6. Simulation of the annual course of cumulated carbon balance $(C B(t))$ of five Pinus pinaster branches during 1998. Grey thick line on time axis denotes the period of branch death. The branch representations give an idea of their structure.

the increasing complexity with age of the number of sources and sinks and of their distribution within the branch structure. However, our study at the branch scale did not allow us to analyse the carbon status of each individual branch organ: among these organs, old needleless shoots located near the branch insertion could have a critical carbon balance, which could endanger the vitality of the branch.

In stand natural conditions the age of branch death is relatively constant from one tree to another. But this event is more or less important according to the year, and the age of death is upper for isolated trees. We tested the importance of these phenomena on the annual carbon balance of branches.

The annual carbon balance of branch b10 in 1998 (9.54 mol C. $\mathrm{y}^{-1}$ in reference conditions) appeared limited by the radiation availability at the branch location (table $V$ ). In the absence of any radiation limitation (as if

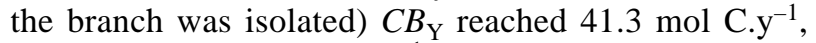
while it was 35.06 mol C. $\mathrm{y}^{-1}$ if the branch was assumed to be located in an isolated tree. In the model, these changes resulted purely from changes in assimilation rate. Here, it appeared that the branch assimilation was less limited by the shade due to the tree on which it was inserted than by the shade produced by the other trees of the stand. The azimuthal direction of this particular branch (South South East) can partly explain this low self-shading.

The carbon balance of branch b10 was also limited by the stomatal control of gas exchange (table $V$ ). In absence of this control, $C B_{\mathrm{Y}}$ was twice larger than in its presence, whereas assimilation only increased by $20 \%$. The dominant climatic control on stomata appeared to be predawn water potential. In any case, the stomatal limitation appeared to be lower than the radiation limitation.

Another application of the model was to simulate the effect of the variability of annual climate on the carbon balance of branches (figure 7). This plot shows the annual carbon balance of three branches (b6, b8, b10) calculated using a climate data set covering the 1980-1998 period. The carbon balance of a branch can vary by up to 20 percent due to climate changes, the main variations being caused by radiation and soil moisture (e.g.: 1990 was a dry year, whereas 1988, 1992 and 1993 had the 
Table V. Annual carbon balance $\left(C B_{\mathrm{Y}}\right)$ and cumulated assimilation in absence of climatic limitations, of branch b10 on 1998.

\begin{tabular}{lcc}
\hline Conditions of simulation & $\begin{array}{c}C B_{\mathrm{Y}} \\
\left(\mathrm{mol} \mathrm{C.y^{-1 }}\right)\end{array}$ & $\begin{array}{c}\text { Cumulated } \\
\text { assimilation } \\
\left(\mathrm{mol} \mathrm{C.} \mathrm{y}^{-1}\right)\end{array}$ \\
\hline Reference & 9.54 & 46.45 \\
$\begin{array}{l}\text { No shade from other vegetal element } \\
\text { No shade from other tree }\end{array}$ & 41.30 & 78.21 \\
$\begin{array}{l}\text { No response of stomata } \\
\text { to air vapour pressure deficit }\end{array}$ & 35.06 & 71.97 \\
$\begin{array}{l}\text { No response of stomata } \\
\text { to radiation condition }\end{array}$ & 11.40 & 48.31 \\
$\begin{array}{l}\text { No response of stomata } \\
\text { to predawn potential }\end{array}$ & 9.95 & 46.86 \\
$\begin{array}{l}\text { No response of stomata } \\
\text { to climatic conditions }\end{array}$ & 15.26 & 52.17 \\
\hline
\end{tabular}

highest rainfall.). Climate affected the carbon balance of all branches with similar magnitude: the difference between the extremes of $C B_{\mathrm{Y}}$ is approximately equal to 13 moles of carbon. However, when compared to the size of the branch, it can be seen that climate affects the younger branch in a more drastic manner. Indeed the biological process most sensitive to the climatic conditions is the assimilation, which has a greater importance in the carbon assessment of the young branches than in that of the old branches.

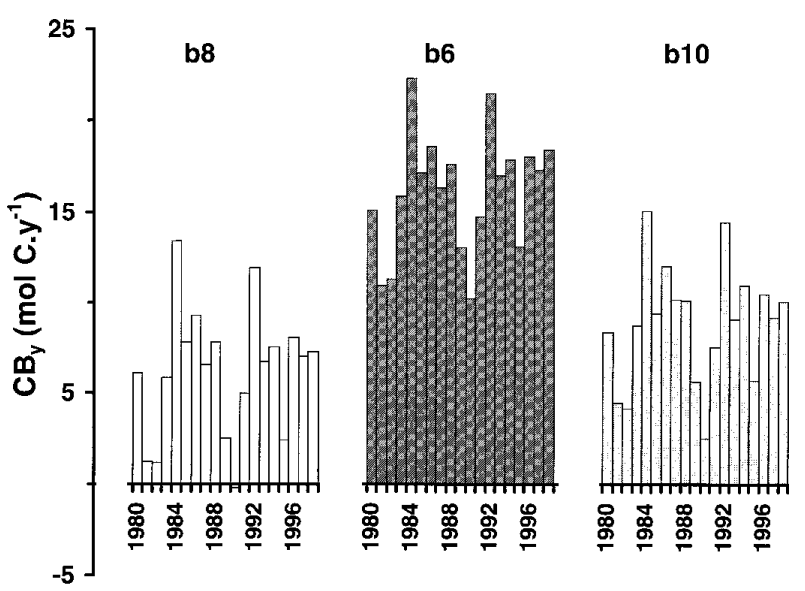

Figure 7. Effect of annual climate on the annual cumulated carbon balance $\left(C B_{\mathrm{Y}}\right)$ of three branches: b8 (2 years-old, top of the crown), b6 (5 years-old, middle of the crown) and b10 ( 9 years-old, bottom of the crown). Simulations of the branch carbon balance were done using annual climate data from 1980 to 1998.
This work suggests that during the years preceding the death of Maritime pine branches, they are not carbon sinks. They are self-sufficient $(A>G+R)$ apart from their first year of life. Until the age of 5 or 6 , branches are marked carbon sources for the rest of the tree. The contribution of the oldest branches to the tree can be neglected; they present lower positive carbon balance, permitting them to cover their own needs until their death. Similar conclusions were advanced for the lowest shaded branches on other conifers [14, 31, 32, 35]). On Pinus pinaster, experiments of artificial branch pruning demonstrated that the removal of the bottom branches of the crown had no negative impact on tree growth (Courdier personal communication). According to the cost-benefit definition of Witowski [35], old branches are probably net sinks for the tree, since they consume water and mineral nutrients while only providing few carbohydrates.

Although branch death occurs during the period when branch benefits for the tree are at their lowest, we can not conclude that a weak branch carbon balance explains branch death. Indeed, this period includes drought stresses, which provokes cavitation that could be deadly to branches.

Our observations are thus not sufficient to conclude on the role of a deficit in carbon balance in branch death. However branch death occurs at a moment where branches don not provide a lot of carbohydrates. We can suppose that branch carbon balance plays an indirect role in branch death: sugar availability decreases relative to the increasing size of the branch, probably impeding the development of a sufficient sap-flow vascular system.

\section{CONCLUSION}

The functional-structural model, EMILION, presented in this paper is based on the technique of discreteness, applied to a tree considered as a sum of organs of several specific types. A tree is modelled as a topological and geometrical organisation of organs and functioning; the latter being potentially the same for each organ of one type. Then, the organ functioning only depends on the microclimate conditions, on the exchanges occurring with the linked organs and on its own characteristics. EMILION has been applied to study adult Maritime pine where the main organ types were shoots, buds and cones. The processes integrated inside the organ functioning are those related to carbon acquisition, carbon use, water transport and evapotranspiration. We chose to model only the processes where experimental knowledge of the functioning in Maritime pine was available. A major use of EMILION is the possibility to test hypotheses 
regarding tree functioning in a coherent manner. For example, we could test assumptions regarding assimilate circulation inside the tree, or the competition between redundant organs for this resource [30].

The first conclusion of our simulation on branches is related to carbon and water functioning: there is a lack of knowledge concerning the internal functioning of organs. Indeed, carbon acquisition through photosynthesis and respiration are quite well-known, whereas carbohydrate storage, their circulation between organs and their use during growth have hardly been considered [16]. Therefore, EMILION imposes the growth and birth of new organs from outside the living organs, by the way of existing measurements supplied by the user. Future experiments should permit to overcome these weaknesses. It would be desirable to carry experiments to answer questions raised by the results of our simulations: follow the sugars in the organs, manipulate sources and sinks in branches, manipulate the branches environment, etc.

Among the hypotheses proposed in the literature to explain branch death $[31,35]$, EMILION adds some information by simulating the carbon balance of branches throughout their life, according to their location within the crown. As expected, branches are generally carbon sources for the rest of the tree. However, the annual carbon balance of the oldest ones hardly exceeds zero, which indicates their weak contribution to the tree global functioning. Our results seem to show that branch death is coincident to a weak or possibly null carbon balance. However, we do not observe a strongly negative carbon balance. This is in agreement with the cost - benefits hypothesis of Witowshi [35].

Acknowledgements: The author gratefully acknowledges A. Porté, B. Medlyn and J.C. Domec for their help in establishing the English text, A. Lardit, F. Bouchet-Lannat and A. Rabot for their help in architectural measurements.

\section{REFERENCES}

[1] Berbigier P., Bonnefond J.-M., Measurement and modelling of radiation transmission within a stand of maritime pine (Pinus pinaster Aït.), Ann. Sci. For. 52 (1995) 23-42.

[2] Bosc A., Étude expérimentale du fonctionnement hydrique et carboné des organes aériens du Pin maritime (Pinus pinaster Aït.) : intégration dans un modèle StructureFonction appliqué à l'analyse de l'autonomie carbonée des branches de la couronne d'un arbre adulte. Thèse de l’Université de Bordeaux II (1999) 192 p.

[3] Bossel H., TREEDYN 3 Forest Simulation Model Mathematical model, program documentation, and simulation results. Berichte des Forschungszentrums Waldökosysteme, Ser. B 35. Göttingen, 118 p.
[4] Cannell M.G.R., Dewar R.C., Carbon allocation in trees: a review of concepts for modelling, Adv. Ecol. Res. 25 (1994) 59-104.

[5] Cannell M.G.R., Morgan J., Theoretical study of variables affecting the export of assimilates from branches of Picea, Tree Physiol. 6 (1990) 257-266.

[6] DeReffye P., Elguero E., Costes E., Growth units construction in trees: stochastics approach, Acta Biotheor. 39 (1991) 325-342.

[7] DeReffye P., Fourcaud T., Blaise F., Barthélémy D., Houllier F., A functional model of tree growth and tree architecture, Silva Fenn. 31 (1997) 297-311.

[8] Desprez-Loustau M.L., Dupuis F., Variation in the phenology of shoot elongation between geographic provenances of maritime pine (Pinus pinaster) - implications for the synchrony with the phenology of the twisting rust fungus, Melampsora pinitorqua, Ann. Sci. For. 51 (1994) 553-568.

[9] Diawara A., Loustau D., Berbigier P., Comparison of two methods for estimating the evaporation of a Pinus pinaster stand: sap flow and energy balance with sensible heat flux measurements by an eddy covariance method, Agric. For. Meteorol. 54 (1991) 49-66.

[10] Farnsworth K.D., Van Gardingen P.R., Allometric analysis of Sitka spruce branches: mechanical versus hydraulic design principles, Trees 10 (1995) 1-12.

[11] Farquhar G.D., Von Caemmerer S., Berry J.A., A biochemical model of photosynthetic $\mathrm{CO}_{2}$ assimilation in leaves of C3 species, Planta 149 (1980) 78-90.

[12] Field C.B., Ball J.T., Berry J.A., Photosynthesis: principles and field techniques, in: Pearcy R.W., Ehleringer J., Mooney H.A., Rundel P.W. (Eds.), Plant physiological ecology: Field methods and instrumentation, Chapman and hall, London, 1989, pp. 209-253.

[13] Granier A., Loustau D., Measuring and modelling the transpiration of a maritime pine canopy from sap-flow data, Agric. For. Meteorol. 22 (1994) 145-148.

[14] Honkanen T., Haukioja E., Why does a branch suffer more after branch-wide than after tree-wide defoliation?, Oikos 71 (1994) 441-450.

[15] Jarvis J.P., The interpretation of the variations in leaf water potential and stomatal conductance found in canopies in the field, Phil. Trans. R. Soc. Lond. B. 273 (1976) 593-610.

[16] Lacointe A., Gary C., Demotes-Mainard S., Vandame M., La répartition des assimilats dans la plante: faits et hypothèses, in: Actes de l'école-chercheurs INRA en bioclimatologie, Unité de bioclimatologie INRA, F-78850 ThivervalGrignon, 1996, pp. 155-180.

[17] Landsberg J.J., Waring R.H., A generalised model of forest productivity using simplified concepts of radiation-use efficiency, carbon balance and partitioning, For. Ecol. Manage. 95 (1997) 209-228.

[18] Le Dizès S., Cruiziat P., Lacointe A., Sinoquet H., Le Roux X., Balandier P., Jacquet P., A model for simulating structure-function relationships in walnut tree growth processes, Silva Fenn. 31 (1997) 313-328. 
[19] Lemoine B., Growth and yield of maritime pine (Pinus pinaster Aït.): the average dominant tree of the stand, Ann. Sci. For. 48 (1991) 593-611.

[20] Loustau D., Domec J.C., Bosc A., Interpreting the variations in xylem sap flux density within the trunk of Maritime pine (Pinus pinaster Ait.): application of a model for calculating water flows at tree and stand levels, Ann. Sci. For. 55 (1998) 29-45.

[21] McMurtrie R.E., Comins H.N., Kirschbaum M.U.F., Wang Y.P., Modifying existing forest growth models to take account of effects of elevated $\mathrm{CO}_{2}$, Aust. J. Bot. 40 (1992) 657677.

[22] Oker-Blom P., Kellomäki S., Smolander H., Photosynthesis of Scots pine shoot: the effect of shoot inclination on the photosynthetic response of a shoot subjected to direct radiation, Agric. Meteorol. 29 (1983) 191-206.

[23] Oker-Blom P., Smolander H., The ratio of shoot silhouette to total needle area in Scots pine, For. Sci. 34 (1988) 894906.

[24] Perttunen J., Sievänen R., Nikinmaa E., Salminen H., Saarenmaa H., Väkevä J., LIGNUM: a tree model based on simple structural units, Ann. Bot. 77 (1996) 87-98.

[25] Poorter H., Villar R., The fate of acquired carbon in plants: chemical composition and construction costs, in: Plant resource allocation, Bazzaz F.A., Grace J. (Eds.), Academic Press, San Diego USA (1997) 39-72.

[26] Porté A., Modélisation des effets du bilan hydrique sur la production primaire et la croissance d'un couvert de Pin maritime (Pinus pinaster Aït.) en Lande humide. Thèse de l'Université de Paris-Sud (1999) 171p.
[27] Porté A., Loustau D., Variability of the photosynthetic characteristics of mature needles within the crown of a 25year-old Pinus pinaster, Tree Physiol. 18 (1998) 223-232.

[28] Running S.W., Gower S.T., FOREST-BGC, a general model of forest ecosystem processes for regional applications, II. Dynamic carbon allocation and nitrogen budgets, Tree Physiol. 9 (1991) 147-160.

[29] Ryan M.G., Linder S., Vose J.M., Hubbard R.M., Dark respiration of pines, Ecol. Bull. 43 (1994) 50-63.

[30] Sachs T., Novoplansky A., Cohen D., Plants as competing populations of redundant organs, Plant Cell. Envir. 16 (1993) 765-770.

[31] Sprugel D.G., Hinckley T.M., Schaap W., The theory and practice of branch autonomy, Ann. Rev. Ecol. Syst. 22 (1991) 309-334.

[32] Uotila A., Mustonen S., The effect of different levels of green pruning on the diameter growth of Pinus sylvestris, L. Scand. J. For. Res. 9 (1994) 226-232.

[33] Wang Y.P., Jarvis P.G., Influence of crown structural properties on PAR absorption, photosynthesis, and transpiration in Sitka spruce, application of a model (MAESTRO), Tree Physiol. 7 (1990) 297-316.

[34] Wang Y.P., Jarvis P.G., Influence of shoot structure on the photosynthesis of sitka spruce (Picea sitchensis) Funct. Ecol. 7 (1993) 433-451.

[35] Witowshi J., Gas exchange of the lowest branches of young Scots pine: a cost-benefit analysis of seasonal branch carbon budget, Tree Physiol. 17 (1997) 757-765. 